\title{
Serbia's Action against Transnational Organised Crime
}

\begin{abstract}
This article aims to examine this question. It will begin by identifying core obligations imposed upon States by the UNTOC. After exploring definitions relating to organised crime stipulated in this instrument, the article will highlight obligations relating to prohibition of substantive offences, as well as the core areas of law enforcement: special investigative techniques (intelligence-led law enforcement), confiscation of criminal proceeds and international law enforcement cooperation. Having explored the relevant international standards, the article will analyse the extent to which these are incorporated and implemented by Serbia through an examination of legislative frameworks as well as law enforcement practices. The main conclusion reached is that, while Serbia has taken some steps to implement international standards with a view to enhancing individual and collective action against transnational organised crime, effective law enforcement is hampered by issues such as corruption and a lack of expertise, experience and resources.
\end{abstract}

\section{Key Words}

Organised crime, law enforcement, Serbia, international law

\section{Introduction}

Transnational organised crime is a serious problem in Serbia. The major criminalities include trafficking of drugs and arms, distribution of counterfeit currencies, vehicle crimes, money laundering and fiscal/exercise fraud. ${ }^{1}$ Human trafficking and migrant smuggling have also been identified as a concern in recent times, the most recent example being the influx of migrants in the wake of the current refugee crisis. It has been estimated that around 60 organised criminal groups of varying sizes and structures are operating nationally, regionally and globally. ${ }^{2}$ Serbia is located on the so-called Balkan route, where goods, services and people are transported illegally into and through its soil. The transnational nature of organised crime requires not only individual actions at the national level, but also collective actions regionally

\footnotetext{
${ }^{1}$ Ministry of Interior, Organised Crime Threat Assessment in Serbia 2015, 123.

${ }^{2}$ Ibid.
} 
and internationally. An important step was taken with the adoption of the United Nations Convention against Transnational Organised Crime (UNTOC) ${ }^{3}$ in 2000. It establishes a number of obligations for Member States to strengthen individual and collective actions against this crime. Serbia is one of the States which ratified this instrument at an early stage, ${ }^{4}$ and this demonstrates its willingness to abide by the relevant international standards stipulated in this instrument. However, the level of their incorporation and implementation through legislative and other means is not entirely clear.

The main purpose of this article, then, is to analyse the extent to which Serbia has facilitated individual and collective actions against transnational organised crime in accordance with the established standards. The article will begin by identifying core obligations imposed upon States by the UNTOC. After exploring a definition of an 'organised criminal group’ stipulated in this instrument, it will highlight relevant obligations relating to prohibition of substantive offences as well as the key areas of law enforcement: special investigative techniques (intelligence-led law enforcement), confiscation of criminal proceeds, and international law enforcement cooperation. Having identified the relevant international standards, the article will examine how Serbia has been able to strengthen its action against transnational organised crime through an analysis of legislative frameworks as well as law enforcement practices. The main conclusion reached is that, while Serbia has taken some steps to enhance its responses in line with the UNTOC, issues such as corruption and a lack of expertise, experience and resources have hampered effective prevention and suppression of transnational organised crime in practice.

\section{International Standards on Action against Transnational Organised Crime}

\footnotetext{
3225 UNTS 209.

${ }^{4} 6$ September 2011.
} 


\title{
2.1 Defining Organised Crime
}

One of the important aspects of the UNTOC is stipulation of various definitions to be adopted by States. To begin with, organised crime is to be understood as a 'serious crime' committed by an 'organised criminal group':

\begin{abstract}
'Organised criminal group' shall mean a structured group of three or more persons, existing for a period of time and acting in concert with the aim of committing one or more serious crimes or offences established in accordance with this convention, in order to obtain, directly or indirectly, a financial or other material benefit. ${ }^{5}$
\end{abstract}

A popular perception of organised crime among the general public perhaps is the involvement of large hierarchical criminal organisations like the Italian mafia, and this was particularly evident in the United States where La Cosa Nostra has been in existence. ${ }^{6}$ It is evident that the above definition of an 'organised criminal group' under the UNTOC does apply to this type of criminal organisations as it refers to a structured group of multiple individuals existing for a certain period of time.

However, it was decided during the drafting stage of the UNTOC that the term would also apply to non-hierarchical groups. ${ }^{7}$ Article 2(c) in this regard stipulates that a structured group does not have to have formally defined roles for its members, continuity of its membership or a developed structure. This also seems to be in line with the scholarly debates particularly within anthropology and political science which took place in the 1970s outside of the United

\footnotetext{
${ }^{5}$ Art 2(a).

${ }^{6}$ See Cressey, D Theft of the Nation (Harper Collins 1969); Cohen, AK, 'The Concepts of Criminal Organisation' (1977) 17 British Journal of Criminology 97; and Fijnaut, C, 'Organized Crime: A Comparison Between the United States of America and Western Europe’ (1990) 30 British Journal of Criminology 321.

${ }^{7}$ Travaux Préparatoires of the Negotiations for the Elaboration of the United Nations Convention against

Transnational Organized Crime and the Protocols Thereto (2006), 7-18.
} 
States $^{8}$ which sustained that the perception of organised criminal groups being hierarchical was too simplistic and did not reflect the reality of contemporary organised crime. ${ }^{9}$ These scholars advocated a so-called 'network model' in which organised crime is understood to be carried out by a collection or network of individuals, small groups and departments, etc. collaborating with each other in varying combination. ${ }^{10}$ In looking at actual examples of organised criminal groups, it becomes apparent that many groups are indeed not hierarchical. Contrary to a popular image, the Medellin and Cali cartels in Colombia consisted of 'loose combinations of relatively small, family based cocaine manufacturing firms that merely joined forces in the early 1980s.'11 It has also been reported that Triads (Hong Kong) and Snakeheads (China) operate largely through informal networks rather than formal structural organisations. ${ }^{12}$ In view of these, it may be concluded that the network model is equally important in understanding organised crime, and that the definition in the UNTOC is broad enough to cover a wide range of criminal groups.

A few more points should be highlighted in relation to the above definition. According to Article 2(b), a ‘serious crime’ means conduct constituting an offence punishable by a maximum deprivation of liberty of at least 4 years. Perceptions on the serious nature of organised crime are inevitably influenced by social, cultural, political and legal characteristics of each State. However, the fact that States have been able to agree on this provision demonstrates that it is possible to find common ground despite differences at national level. The UNTOC also defines ‘criminal offences’ as those being committed for financial or material benefit. This is an

\footnotetext{
${ }^{8}$ McIllwain, J, ‘Organised Crime: A Social Network Approach’ (1999) 32 Crime, Law and Social Change 301, 303.

${ }^{9}$ Williams, P, and Godson, R, ‘Anticipating Organized and Transnational Crime’ (2002) 37 Crime, Law and Social Change 311, 332.

${ }^{10}$ Bruinsma, G, and Bernasco, W, 'Criminal Groups and Transnational Illegal Markets’ (2004) 41 Crime, Law and Social Change 79, 79.

${ }^{11}$ Paoli, L, 'The Paradoxes of Organised Crime’ (2000) 37 Crime, Law and Social Change 51, 68.

${ }^{12}$ Zhang, S, and Chin, KL, Characteristics of Chinese Human Smugglers: A Cross-National Study (U.S. Department of State 2003); and Chu, YK, The Triads as Business (Routledge 2008).
} 
important aspect because what distinguishes organised crime from ordinary crime generally is the generation of longer-term, as opposed to immediate or one-off, profit or benefit. ${ }^{13}$ This means that criminal proceeds are normally diversified and reinvested in legal/illegal enterprises for generation of sustained income for criminals. ${ }^{14}$ Organised criminal groups therefore are comparable to legitimate corporations and businesses, except that they mainly operate in illegal markets.

\subsection{Prohibition of Organised Crime}

The first important obligation under the UNTOC is the prohibition of organised crime. In addition to serious crimes committed by organised criminal groups, the UNTOC obliges States to criminalise so-called participation offences. ${ }^{15}$ The rationale for this inclusion is to prosecute and punish those who contribute to the operations of organised crime groups without directly committing substantive offences such as drug trafficking and money laundering. ${ }^{16}$ This can therefore be used to target mafia bosses who simply order their subordinates to commit various crimes, for instance. There are two possibilities provided in Article 5 of the UNTOC. The first is criminalising an agreement to commit crimes. This is also known as 'conspiracy' and is widely accepted by common law jurisdictions. The key aspect is that one can be prosecuted even when an offence is not actually committed. However, this offence is not supported universally, particularly by civil law jurisdictions. ${ }^{17}$ In order to accommodate these States, Article 5 provides for another possibility: criminalisation of participation in the activities of organised criminal

\footnotetext{
${ }^{13}$ Obokata, T, Transnational Organised Crime in International Law (Hart Publishing 2010), 22.

${ }^{14}$ Schloenhardt, A, 'Organised Crime and the Business of Migrant Trafficking: an Economic Analysis' (1999) 32 Crime, Law and Social Change 203; and Cressey, supra n 6, 72.

${ }^{15}$ Art 5.

${ }^{16}$ United Nations Office of Drugs and Crime (UNODC), Legislative Guides for the Implementation of the United Nations Convention against Transnational Organised Crime and Protocols Thereto (2004), 21.

${ }^{17}$ Obokata, supra n 13, 40-42.
} 
groups, which requires actual conduct. This generally covers activities which may not be criminal in nature on their own but still contribute to the achievement of a criminal aim. So for instance, arranging transportation for criminals and purchasing property can fall under this. The ambit therefore is wide, and this can raise an issue of legal certainty. One mitigation here is the requirement of the 'knowledge' by a participant that his/her participation would help a group achieve its criminal objectives. Acts such as carrying illegal goods without one knowing therefore are not to be criminalised. Finally, so-called secondary participation (e.g. aiding and abetting) is to be punished under Article 5.

The UNTOC also obliges States to address risk-averting strategies employed by criminals. Money laundering is one example. ${ }^{18}$ Proceeds obtained as a result of organised crime are diversified and reinvested through this method. There are three stages in the money laundering process. The first is placement where illegal proceeds enter into the financial system. A technique known as 'smurfing' (or 'structuring') - dividing the proceeds into smaller bundles is used in order to avoid detection through reporting or record-keeping by financial institutions. The second stage is laying where proceeds are moved from one place to another so as to conceal their origin. Overseas offshore banks, which do not always have strict regulations, are often used for this purpose. The final stage is integration where the proceeds are returned to the financial system. It is extremely difficult, if not impossible, to take action at this stage as the proceeds appear legitimate. Therefore, it is essential that State Parties establish sufficient legal and administrative frameworks to detect and prosecute this offence. States also must address other risk-averting strategies such as corruption and obstruction of justice. ${ }^{19}$ Bribery and a threat/use

\footnotetext{
${ }^{18}$ Art 6.

${ }^{19}$ Arts 8 and 23 of the UNOTC. See also the United Nations Convention against Corruption 2003, 2349 UNTS 41.
} 
of violence against victims, witnesses, as well as jurors in criminal proceedings are common tactics used by criminals to avoid law enforcement. ${ }^{20}$

Aside from these offences under the UNTOC, other subject-specific international treaties oblige States to prohibit various forms of organised crime such as migrant smuggling, ${ }^{21}$ trafficking of firearms, ${ }^{22}$ drugs, ${ }^{23}$ cultural property, ${ }^{24}$ endangered species, ${ }^{25}$ and nuclear materials, ${ }^{26}$ illicit trade in tobacco products, ${ }^{27}$ child pornography, ${ }^{28}$ cybercrime $^{29}$ counterfeiting ${ }^{30}$ and slavery/forced labour. ${ }^{31}$ In view of these, it seems reasonable to conclude that international law on transnational organised crime as represented by these legal instruments establish a clear obligation to criminalise organised crime and related conducts. In particular, the UNTOC is broad enough to cover the existing as well as new and emerging criminalities as it is not subject-specific. At the national level, although flexibility is necessary in order to allow States to formulate domestic criminal laws in accordance with their legal, political, social and cultural traditions, it is simultaneously important that the principle of legality is fully observed in

\footnotetext{
${ }^{20}$ See for instance, UNODC, The Role of Corruption in Trafficking in Persons (UNODC 2011); Kugler, M, Verdier, T, and Zenou, Y, 'Organised Crime, Corruption and Punishment' (2005) 89 Journal of Public Economics 1639; and Mass, S, 'The Dilemma of the Intimidated Witness in Federal Organised Crime Prosecution: Choosing among the Fear of Reprisal, the Contempt Powers of the Court, and the Witness Protection Programme' (1981-1982) 50 Fordham Law Review 582.

${ }^{21}$ Protocol against the Smuggling of Migrant by Land, Sea and Air 2000, 2241 UNTS 507.

${ }^{22}$ Protocol against the Illicit Manufacturing and Trafficking in Firearms, Their Parts and Components and Ammunition 2001, 2326 UNTS 208.

${ }^{23}$ United Nations Convention against Illicit Traffic in Narcotic Drugs and Psychotropic Substances 1988, 1582 UNTS 95.

${ }^{24}$ Convention on the Means of Prohibiting and Preventing the Illicit Import, Export and Transfer of Ownership of Cultural Property 1970 (UNESCO Cultural Convention), 823 UNTS 231; Convention for the Protection of the World Cultural and Natural Heritage 1972, 11 ILM 1358; and Convention on the Protection of Archaeological, Historical and Artistic Heritage of the American Nations 1976, 15 ILM 1350.

${ }^{25}$ Convention on International Trade in Endangered Species of Wild Fauna and Flora 1973, 993 UNTS 243.

${ }^{26}$ Convention on the Physical Protection of Nuclear Material 1979, 18 ILM 1419.

${ }^{27}$ Protocol to Eliminate Illicit Trade in Tobacco Products 2012 to the WHO Framework Convention on Tobacco Control, Decision FCTC/COP5 (1).

${ }^{28}$ Optional Protocol to the Convention on the Rights of the Child on the Sale of Children, Child Prostitution and Child Pornography 2000, 2171 UNTS 227.

${ }^{29}$ Council of Europe Convention on Cyber Crime 2001, ETS No. 187.

${ }^{30}$ International Convention for the Suppression of Counterfeiting Currency 1929, 112 LNTS 371.

${ }^{31}$ Slavery Convention 1926, 60 UNTS 254; and ILO Convention (No. 29) Concerning Forced and Compulsory Labour 1930, 39 UNTS 55.
} 
defining and establishing organised crime offences, which is also a well-established principle under international law. ${ }^{32}$

\subsection{Intelligence-Led Law Enforcement}

The sophisticated nature of organised crime and the modus operandi means that proactive intelligence-led law enforcement must be facilitated for successful prevention and suppression, as opposed to reactive law enforcement which is conducted after crimes are committed. Article 20 of the UNTOC is important in this regard. For instance, it provides for controlled delivery. Article 2(i) defines this as 'the technique of allowing illicit or suspect consignments to pass out of, through or into the territory of one or more States, with the knowledge and under the supervision of their competent authorities, with a view to the investigation of an offence and the identification of persons involved in the commission of the offence.' Controlled delivery is often employed in the investigation and prosecution of drug related offences. ${ }^{33}$ The UNTOC also obliges States to consider allowing other techniques such as electronic surveillance and undercover operations. The obligations under this Article are not strong as it uses phrases such as 'if permitted by the basic principles of its domestic legal system' and 'within its possibilities.' Indeed, the interpretative note on this Article makes it clear that it 'does not imply an obligation on State Parties to make provision for the use of all forms of special investigative technique' and a degree of reluctance to be bound by hard obligations was also evident during the drafting

\footnotetext{
${ }^{32}$ See for instance, art. 15(1) of the International Covenant on Civil and Political Rights 1996 (ICCPR), 999 UNTS 171 , which provides that 'no one shall be held guilty of any criminal offence on account of any act or omission which did not constitute a criminal offence, under national or international law, at the time when it was committed. Nor shall a heavier penalty be imposed than the one that was applicable at the time when the criminal offence was committed.'

${ }^{33}$ Supra n 23, art 11; and Lee, GD, Global Drug Enforcement: Practical Investigative Techniques (CRC Press 2004), 255.
} 
stage. $^{34}$ Article 20 also encourages States to facilitate international cooperation in using these techniques through bilateral or multilateral arrangements. This is supplemented by Article 28, which touches upon collection, analysis and sharing of intelligence on organised crime.

\subsection{Confiscation of Criminal Proceeds}

Another important obligation to be implemented at the national level is confiscation of criminal proceeds or asset recovery. An effective regime of confiscation can send a strong message to criminals that they are not able to benefit from their criminal activities, and this may have a degree of deterrent effect. It can also significantly disrupt criminal activities or even dismantle criminal organisations. ${ }^{35}$ The first international instrument touching upon this is the UN Convention against Illicit Traffic in Narcotic Drugs and Psychotropic Substances 1988, ${ }^{36}$ and the UNTOC has made it relevant to different forms of organised crime. To being with, Article 12 obliges States to take necessary measures to confiscate criminal proceeds or property whose value corresponds to that of such proceeds. States also have to target other property converted from criminal proceeds as well as income and other benefits generated from such proceeds. In addition, Article 12 makes it clear that States are not to rely on bank secrecy to evade their obligations and also are allowed to require offenders to prove the lawful origin of alleged proceeds, shifting the burden of proof from the prosecution.

Confiscation of criminal proceeds can be divided roughly into two categories. The first is conviction-based confiscation. As the name suggests, a confiscation order is issued after one is convicted of organised crime. In addition, some States, including Australia, Canada, Ireland,

\footnotetext{
${ }^{34}$ Travaux Préparatoires, supra n 7, 205-206.

${ }^{35}$ Vettori, B, Tough on Criminal Wealth: Exploring the Practice of Proceeds from Crime Confiscation in the EU (Springer 2006), 3.

36 Supra n 23, art 5.
} 
Italy, the United Kingdom, and the United States of America, ${ }^{37}$ also rely on non-convictionbased confiscation. This can be facilitated through civil proceedings, using 'balance of probabilities' as the standard of proof, without conviction. For this reason, non-conviction-based confiscation is sometimes referred to as 'civil asset recovery' in some jurisdictions such as the United Kingdom and Ireland. Here, the guilt is not associated with property and not the offenders. A practical implication of this divergence in confiscation regimes is that it can make international cooperation somewhat difficult as many States, particularly civil law jurisdictions, do not rely upon non-conviction-based asset recovery, for instance. A high degree of mutual respect and recognition therefore is needed among State Parties in facilitating cross-border confiscation of criminal proceeds.

\subsection{International Cooperation}

The main aim of the UNTOC is to promote cooperation for more effective prevention and suppression of transnational organised crime, ${ }^{38}$ and it establishes a number of obligations in this regard. One example is extradition under Article 16. This is facilitated mainly by bilateral and/or multilateral treaties. International instruments touching upon various types of organised crime such as corruption and drug trafficking also have provisions on extradition. ${ }^{39}$ As the consolidated version of these relating to organised crime, the UNTOC provides detailed guidance on extradition under Article 16. The benefit of this provision is that it applies to all regions of the world, unlike the geographically limited regional treaties. ${ }^{40}$ Furthermore, it

\footnotetext{
${ }^{37}$ Sambei, A, Civil Forfeiture (Confiscation in Rem): Explanatory and Impact Study (Council of Europe 2012 ), 5.

${ }^{38}$ Art 1.

39 Supra n 23, art 6; supra n 28, art 5; supra n 19, art 44; and supra n 27, art 30.

${ }^{40}$ See for instance, Inter-American Convention on Extradition 1981, 20 ILM 723; European Convention on Extradition 1957, ETS. No. 24; and Economic Community of West African States Convention on Extradition 1994, A/P.1/8/94.
} 
applies to almost all instances of organised crime, and therefore does not limit itself to particular crimes stipulated under the subject specific conventions. At the time of ratification or accession, States can choose to use the UNTOC as a legal basis to facilitate extradition in the absence of the pre-existing treaties. It is worth point out here that in 2008, 59 Member States stated that the UNTOC was to be taken as a legal basis for extradition. ${ }^{41}$ This does demonstrate that this instrument has been valued by a number of States.

Several aspects of Article 16 should be expanded. The principle of aut dedere aut judicare (extradite or prosecute) is explicitly recognised. This principle becomes relevant particularly when States do not extradite their nationals, including Serbia. ${ }^{42}$ The facilitation of simplified procedure for extradition is also provided for. ${ }^{43}$ A good example of this is the system of European Arrest Warrant ${ }^{44}$ adopted by the European Union and its Member States, which has significantly shortened the amount of time it takes to surrender suspects or defendants. ${ }^{45}$ In addition, Article 16(14) provides that:

Nothing in this Convention shall be interpreted as imposing an obligation to extradite if the requested State Party has substantial grounds for believing that the request has been made for the purpose of prosecuting or punishing a person on account of that person's sex, race, religion, nationality, ethnic origin or political opinions or that compliance with the request would cause prejudice to that person's position for any one of these reasons.

This so-called 'discrimination clause' is crucial from a human rights perspective. While the inclusion of the imposition of the death penalty and trial in absentia as additional grounds for refusal was debated during the drafting stage, it was later concluded that the sentence

\footnotetext{
${ }^{41}$ Information Submitted by States in their Responses to the Checklist/Questionnaire on the Implementation of the United Convention against Transnational Organised Crime for the First Cycle, CTOC/COP/2008/CPR.7, 17-20.

${ }^{42}$ See below for more information.

${ }^{43}$ Art 16(8).

${ }^{44}$ Council Framework Decision 2002/584/JHA of 13 June 2002 on the European arrest warrant and the surrender procedures between Member States, [2002] OJ L 190/1.

45 This regime will be relevant to Serbia when it becomes an EU Member State in the future.
} 
'extradition shall be subject to the conditions provided for by domestic law' would be sufficient to cover other grounds. ${ }^{46}$

Another important provision under the UNTOC relates to mutual legal assistance in criminal matters. This is also facilitated bilaterally ${ }^{47}$ or multilaterally, ${ }^{48}$ the UNTOC being the latest instrument. The most important provision is Article 18 which encourages State Parties to facilitate the following measures:

(a) Taking of evidence or statements from other persons:

(b) Effecting service of judicial documents;

(c) Executing searches and seizures, and freezing;

(d) Examining objects and sites;

(e) Providing information, evidentiary items and expert evaluations;

(f) Providing originals or certified copies of relevant documents and records, including government, bank, financial, corporate or business records;

(g) Identifying or tracing proceeds of crime, property, instrumentalities or other things for evidentiary purposes;

(h) Facilitating the voluntary appearance of persons in the requesting State Party; and

(i) Any other type of assistance that is not contrary to the domestic law of the requested State Party.

The ambit of mutual legal assistance therefore is wide depending on the domestic law of each State Party.

There are other important points to highlight in this provision. Paragraph 8 provides that States cannot refuse mutual legal assistance on the basis of bank secrecy. This makes action

\footnotetext{
${ }^{46}$ Travaux Préparatoires, supra n 7, 152 and 155.

${ }^{47}$ See, for instance, Mutual Legal Assistance in Criminal Matters (Australia) Order 1999 (Hong Kong); and Mutual Assistance in Criminal Matters (Malaysia) Regulations 2006 (Australia).

${ }^{48}$ European Convention on Mutual Assistance in Criminal Matters 1959, ETS. No. 30; Inter-American Convention on Mutual Assistance in Criminal Matters 1992, OASTS No. 75; ASEAN Treaty on Mutual Legal Assistance in Criminal Matters; and Southern African Development Community Protocol on Mutual Assistance in Criminal Matters 2002. See McClean, M, International Cooperation in Civil and Criminal Matters (Oxford University Press 2002), Chapter 6.
} 
against money laundering much easier. Another interesting part is paragraph 9 on double criminality. The draft paragraph initially stated that States 'may not decline’ mutual legal assistance on the absence of double criminality. The actual wording of paragraph 9, however, has been changed to 'may decline.' Some delegations during the drafting stage emphasised the importance of double criminality in mutual assistance, ${ }^{49}$ and it is evident that their view prevailed. However, as a compromise, the same paragraph leaves open a possibility of providing assistance on a discretionary basis even in the absence of double criminality. In addition, although the draft Article stated that offences covered in the UNTOC were not to be regarded as political in nature, ${ }^{50}$ the final version does not contain this sentence. Organised crime can therefore be designated as a political offence for the purpose of mutual legal assistance. Indeed, the interpretative note stipulates the possibility of the political offence exception. ${ }^{51}$ This should also be contrasted with Article 16 on extradition where it clearly states that offences under the UNTOC should be deemed extraditable (hence the political offence exception does not apply). Finally, the international community missed an important opportunity to include a discrimination clause as an additional ground for refusal of mutual legal assistance, which was included in Article 16 on extradition. Although the United States proposed this clause during the drafting stage, some delegates took a view that refusal on the ground of 'other essential interest' would cover this, ${ }^{52}$ and the clause was eventually dropped. Worryingly, these inconsistencies can send conflicting messages to State Parties.

There are a few more provisions which are relevant to international cooperation. The first is Article 19 on joint investigations. It encourages States to establish joint investigatory

\footnotetext{
${ }^{49}$ Travaux Préparatoires, supra n 7, 177.

${ }^{50}$ Ibid, 170.

${ }^{51}$ Ibid, 199.

${ }^{52}$ Ibid, 185.
} 
bodies through agreement or on a case-by-case basis. During the drafting stage, whether this regime should be included as part of general mutual legal assistance was considered, but it was decided that a separate provision should be created. ${ }^{53}$ Once again, this has become an important mechanism within the EU context ${ }^{54}$ at least. The second is Article 13 on international cooperation in confiscation of criminal proceeds whereby States are to identify, trace and confiscate proceeds when requested by other States. Finally, transfer of criminal proceedings (Article 21) and direct law enforcement cooperation (Article 27) are also encouraged. The latter is important as it can reduce political interferences as well as time to execute cooperation. In looking at these provisions, it is evident that the UNTOC provides a broad framework to encourage international law enforcement cooperation against transnational organised crime.

\section{Implementation of International Standards in Serbia}

\subsection{Prohibition of Substantive Offences}

Having identified the important international standards on the action against transnational organised crime, it is now useful to explore the extent to which these are implemented in Serbia. With respect to definition of organised crime in national legislation, three statutes are pertinent: the Criminal Procedure Code (CPC), ${ }^{55}$ the Act on Organisation and Jurisdiction of Government Authorities in the Suppression of Organised Crime, Corruption and Other Severe Criminal Offences, ${ }^{56}$ and the Criminal Code (CC).${ }^{57}$ Firstly, the CPC defines organised crime as the commission of criminal offences by an organised criminal group or its members. ${ }^{58}$ Under this Code, organised criminal group means:

\footnotetext{
${ }^{53}$ Ibid, 202.

${ }^{54}$ Council Framework Decision of 13 June 2002 on joint investigation teams, [2002] OJ L 162/1; and Convention on Mutual Legal Assistance in Criminal Matters between the EU Member States 2000, art 13, [2000] OJ C 197/1.

${ }^{55}$ Official Gazette of the Republic of Serbia, No 72/2011, as amended.

${ }^{56}$ Official Gazette of the Republic of Serbia, No 42/2002, as amended.

${ }^{57}$ Official Gazette of the Republic of Serbia, No 85/2005 as amended.

${ }^{58}$ Art 2(1)(34).
} 
a group of three or more persons, which exists for a certain period of time and acts in collusion with the aim of committing one or more criminal offences punishable by a term of imprisonment of four years or a more severe punishment, for the purpose of direct or indirect acquisition of pecuniary or other gain ${ }^{59}$

The Act on Organised Crime also contain a definition which are identical to the CPC. ${ }^{60}$ Here, it is clear that these definitions are in line with the UNTOC. Interestingly, however, the CC provides an additional definition of 'organised group.' Article 112(22) defines it as a group comprising 'minimum of three persons acting in conspiracy to commit criminal offences.' The fact that a separate definition was adopted indicates that it applies to those other than organised criminal groups whose main aim is not necessarily obtaining pecuniary or other benefits. So for instance, a group of youths causing criminal damage or assaulting innocent citizens would come under this definition.

It is worth expanding whether the above definition can be applied to criminal groups operating in Serbia. As noted earlier, there are around 60 organised criminal groups operating in and out of Serbia. These are groups are mainly structured in a horizontal manner, in that their structure is not really hierarchical like the Italian mafia. ${ }^{61}$ In this regard, only $8.6 \%$ of these groups are said to have a high level of organisation. ${ }^{62}$ This suggests that the network model of an organised criminal group seems to be dominant in this country. Further, about $25 \%$ of members working for groups with high level of organisation are said to be foreign nationals. ${ }^{63}$ This perhaps is inevitable given the geographical location of Serbia in the Balkan region which are used as transit for illegal goods and even people, thereby necessitating criminals in various neighbouring States to work together. In contrast, criminal groups with a low level of

\footnotetext{
${ }^{59}$ Art 2(1)(33).

${ }^{60}$ Art 3.

${ }^{61}$ Papandera, D, 'Serbia’ in Forte, R (ed.) Organised Crime and Fight against Crime in West Balkans: A Comparison with the Italian Models and Practices (SAPUCCA 2013), 32

${ }^{62}$ Ministry of Interior, supra n 1, 123.

${ }^{63}$ Ibid.
} 
organisation (the network type) are seem to be actively locally and not internationally with a lesser number of foreign criminals. ${ }^{64}$ An important point to stress, however, is that many of these groups are connected one way or another in carrying out a variety of criminal activities, thereby demonstrating the complex nature of their operations as well as working relationships. In any event, it seems reasonable to argue that the definitions of organised criminal groups in the CPC and the Act on Organised Crime are wide enough to prosecute punish these groups operating in Serbia.

In relation to prohibition of organised crime offences, the CC does not explicitly provide for participation offences explored above. However, certain aspects can be punished by the relevant provisions. For instance, Article 345 creates an offence of conspiracy to commit an offence carrying at least 5 years' imprisonment. Here, the threshold is higher than 4 years under the definition of 'serious crime' in the UNTOC, clearly demonstrating a different understanding of 'seriousness'. The punishment for conspiracy is a fine or imprisonment of up to 1 year. Given the amount of profits criminals can make, it is doubtful whether this level of punishment can serve as effective deterrence. Another relevant offence is 'criminal alliance. ${ }^{65}$ Under this, organising a group whose aims is to commit criminal offences carrying imprisonment of 3 years or more, as well as becoming a member of such group are prohibited. The ambit of these offences is wide as these are not restricted to 'organised criminal group.' Also, the lower threshold of 3 years is used for this offence, and this shows that there is no uniform understanding of ‘seriousness’ under Serbian criminal law. Further, inconsistency is evident in relation to the levels of punishments (3 to 5 years), and this can have a negative impact on effective suppression of participation offences.

\footnotetext{
${ }^{64}$ Ibid.

${ }^{65}$ Art 346.
} 
Aside from participation offences, Serbia criminalises various forms of organised crime. One example is drug trafficking. This is a serious problem due to the fact that Serbia is a major transit route for illegal drugs (e.g. the Balkan Route). ${ }^{66}$ The group of criminal offences in this connection includes unlawful production and distribution (Article 246 CC), unlawful keeping (Article 246 (a) CC) and facilitating the consumption (Article 247 CC). In relation to unlawful production, it is worth highlighting that the involvement of organised criminal groups is regarded as an aggravating factor, attracting a minimum penalty of 10 years' imprisonment. The recent case of Darko Šarić is worth mentioning in this regard. He was a member of an organised criminal group and was convicted of trafficking 5.7 tonnes of cocaine from Latin America to Western Europe and was sentenced to 20 years' imprisonment in 2015. There were also related proceedings against others, and 21 member of his organised criminal group were eventually convicted and imprisoned for a combined total of 256 years and 11 months. Involvement of an organised crime as an aggravating factor can be seen in other offences proscribed by the CC, such as kidnapping, ${ }^{67}$ extortion, ${ }^{68}$ and blackmailing. ${ }^{69}$ This is an example of good practice as the statute seems take the serious, dangerous and sophisticated nature of organised crime into consideration in relation to sentencing.

In addition, human trafficking has been identified as a growing crime in Serbia. In addition to drugs, people are also trafficked to Western Europe through the Balkan Route, the most prominent example being the ongoing refugee crisis originating in Syria. This offence was

\footnotetext{
${ }^{66}$ U.S. Department of State, International Narcotics Control Strategy Report 2015, at $<$ www.state.gov/j/inl/rls/nrcrpt/2015/vol1/239011.htm> (last accessed 10 May 2016).

${ }^{67}$ Art 134.

${ }^{68}$ Art 214.

${ }^{69}$ Art 215.
} 
introduced originally in 2003, ${ }^{70}$ but was amended when the new CC came into force in 2006.

Article 338 provides that:

Whoever by force or threat, deception or maintaining deception, abuse of authority, trust, dependency relationship, difficult circumstances of another, retaining identity papers or by giving or accepting money or other benefit, recruits, transports, transfers, sells, buys, acts as intermediary in sale, hides or holds another person with intent to exploit such person's labour, forced labour, commission of offences, prostitution, mendacity, pornography, removal of organs or body parts or service in armed conflicts, shall be punished by imprisonment of two to twelve years.

It is worth comparing this with the international definition of human trafficking adopted by the Protocol to Prevent, Suppress and Punish Trafficking in Persons $2000^{71}$ attached to the UNTOC:

Trafficking in persons shall mean the recruitment, transportation, transfer, harbouring or receipt of persons, by means of the threat or use of force or other forms of coercion, of abduction, of fraud, of deception, of the abuse of power or of a position of vulnerability or of the giving or receiving of payments or benefits to achieve the consent of a person having control over another person, for the purpose of exploitation. ${ }^{72}$

The main conduct or actus reus of trafficking under the Serbian legislation is broadly in line with this international definition. The willingness of the Serbian government to abide by the international standards therefore can be recognised to some extent. However, variations also exist between the two definitions, particularly in relation to the element of exploitation, and this shows that the principle of State sovereignty is dominant in action against transnational organised crime.

Further, risk averting activities are also criminalised by the CC. For instance, money laundering ${ }^{73}$ carries an imprisonment of between 6 months to 5 years. Compared to other jurisdictions such as the United Kingdom, ${ }^{74}$ the punishments seem somewhat weak. However, aggravating factors are simultaneously recognised. One would, for instance, face up to 10 years’ imprisonment when the amount of laundered money exceeds 1.5 million Serbian dinars

\footnotetext{
${ }^{70}$ Art $111 \mathrm{~b}$.

${ }^{71} 2237$ UNTS 319.

${ }^{72}$ Art 3.

${ }^{73}$ Art 231.

${ }^{74}$ The offence is punishable by imprisonment of up to 14 years under the Proceeds of Crime Act 2002.
} 
(approximately $\$ 14,000)$. If the offence is committed by a 'group,' the punishments would range from 2 to 12 years' imprisonment, although this is not limit to organised criminal groups. In addition, soliciting and receiving bribes are also prohibited with the imprisonment of up to 12 years, whereas offering them would attract up 5 years. ${ }^{75}$ Further, obstruction justice (bribing and using/threatening violence against witnesses) is proscribed. ${ }^{76}$ In summary, substantive criminal law in Serbia does cover a range of organised crime offences and related conducts.

\subsection{Law Enforcement}

In Serbia, the key law enforcement measures against transnational organised crime explored earlier are governed by national legislation. For instance, special investigative techniques are stipulated in Chapter VII of the CPC (Articles 161-187). It lists six measures: interception of communications, surveillance and recording, simulated activities, computer data search, controlled delivery and undercover investigation. ${ }^{77}$ These measures can only be used for crimes listed under Article 162 including various forms of organised crime, and this underscores their special status. A few of these measures are worth expanding. Interception of communications involves the interception and recording of communications conducted by telephone or other technical means (e.g. faxes, e-mails, and mobile phones), surveillance of electronic or other address of the suspect, as well as seizure of letters and other parcels. ${ }^{78}$ Covert surveillance and recording of suspects in turn can be used to detect contacts or communications of a suspect in public places and places where access is limited, or to determine the identity of a

\footnotetext{
${ }^{75}$ Arts 367 and 368.

${ }^{76}$ Art 336, which provides for 5 years’ imprisonment.

${ }^{77}$ Bošković, A., Pavlović, Z, 'Special Evidentiary Actions in the Function of Combating Organized Crime in Serbia' (2015) Journal of Eastern-European Criminal Law 40, 43.

${ }^{78}$ Art 166.
} 
person or locate persons or objects. ${ }^{79}$ The main difference between these two measures is that interception involves communications through technical means, while in surveillance and recording, the primary focus is placed upon visual observation and surveillance of the person, with the second component being the surveillance of communications conducted 'live'. By 'simulated activities,' the CPC means simulate purchase, sale or rendering of business services and/or simulated offering/accepting of bribes. ${ }^{80}$ Finally, undercover investigators can be deployed only if evidence cannot be collected through other means, suggesting that this is a method of last resort.

An important point to stress here is that judicial approval is required for most of these measures. ${ }^{81}$ Judges can also request recorded materials for examination. ${ }^{82}$ Given the intrusive nature of special investigative techniques, these safeguards are quite important as they can prevent potential abuse on the part of the law enforcement agencies and protect the human rights of those affected. ${ }^{83}$ The legislation in the United Kingdom ${ }^{84}$ does not currently provide for prior judicial authorisation for measures such as interception of communications, and therefore the Serbian legal framework is an example of good practice. Having said this, the CPC does not require prior judicial authorisation for controlled delivery and it is given by a prosecutor instead. On the one hand, some European States such as Belgium, Bulgaria and the Czech Republic also entrust their prosecutors to give such an authorisation, ${ }^{85}$ and there is no problem with this arrangement in principle as it may not affect one’s right to privacy as much as other measures.

\footnotetext{
${ }^{79}$ Art 171.

${ }^{80}$ Art 174.

${ }^{81}$ Arts 167, 172, 175, 179, and 184.

${ }^{82}$ Arts 168, 171, 176, 180 and 186.

${ }^{83}$ Ivanović, Z, and Banović, B, Analysis of Legal Regulation on Communication Surveillance and Jurisprudence of the European Court of Human Rights (Analiza Pravne Regulative Nadzora nad Komunikacijama i Praksa Evropskog Suda za Ljudska Prava) (Bezbednost, 2011), 104-105.

${ }^{84}$ Regulation of Investigatory Powers Act 2000.

${ }^{85}$ Eurojust, Issue in Focus No. 1: Cross-Border Controlled Deliveries from a Judicial Perspective (January 2015).
} 
On the other hands, judicial approval does enhance accountability and impartiality, and judges authorise controlled delivery in other States such as Italy and Lithuania. ${ }^{86}$ Therefore, there is scope for further consideration in Serbia.

A few more issues should be mentioned in relation to special investigative techniques. While the CPC states that interception of communications should last no longer than three months, this period can be extended for further three months. ${ }^{87}$ Exceptionally, for criminal offences under the jurisdiction of the Prosecutor's Office for Organised Crime or the Prosecutor's Office for War Crimes, this period can be extended two more times. ${ }^{88}$ This in fact means the law enforcement authorities can use this measure for a full year, and this is problematic from a human rights perspective. In addition, interception relates to communications through telephone and other means and does not apply to direct oral conversations, thereby leaving a law enforcement gap. A question has been raised as to whether surveillance can fill this gap by covering sound recording. The CPC makes it clear that this is used for the purpose of detecting communications, and does not explicitly authorise recording of the suspect's communications per se. Because of this, some have argued that these should only apply to visual recording. ${ }^{89} \mathrm{~A}$ degree of uncertainly therefore remains, potentially affecting the ability of law enforcement authorities to detect organised crime.

In addition to special investigative techniques, confiscation of the proceeds of crime is provided for under two laws in Serbia. The first is the CC. Confiscation is governed by Articles 91-93, and the first point to highlight is that it is not regarded as a criminal sanction, but as having a sui generis character. The confiscation of material gains is based on the explicit

\footnotetext{
${ }^{86}$ Ibid.

${ }^{87}$ Art 167.

${ }^{88}$ Ibid.

89 Škulić, M, and Ignjatović, Đ, Organised Criminality (Organizovani kriminalitet) (Belgrade University 2012), 371-372.
} 
principle enshrined Article 91 that no one is allowed to retain the proceeds obtained by criminal offence. It then follows that confiscation of such proceeds is mandatory. ${ }^{90}$ Under relevant provisions of the CC, confiscation can be enforced only in the presence of evidence that the respective proceeds originate from a crime. This means that prior criminal conviction of a suspect is necessary. In this regard, similar to other civil law jurisdictions in the continental Europe, Serbia does not recognise non-conviction-based confiscation such as civil asset recovery.

The second relevant statute is the Act on Seizure of the Proceeds from Crime. ${ }^{91}$ This law applies to a limited number of crimes as stipulated in Article 2, such as organised crime, child pornography and drug offences. It complements the CC as it provides for 'extended confiscation of property' (i.e. confiscation of property for which the convicted person is unable to prove its lawful origin). ${ }^{92}$ In this case, the burden is placed upon the defendant to prove their lawful origin, rather than on public prosecutor. ${ }^{93}$ While this may have implications for the human rights of defendants, such as presumption of innocence, it has been held by the European Court of Human Rights in the past that the purpose of confiscation proceedings is to recover proceeds illegally obtained and not to determine one’s guilt. ${ }^{94}$ However, it has been pointed out that this extended confiscation may not properly work when the owner claims that the property

\footnotetext{
${ }^{90}$ Stojanović, Z, Commentary to the Criminal Code (Komentar Krivičnog zakonika) (OSCE Mission to Montenegro 2010), 270-271.

${ }^{91}$ Official Gazette of the Republic of Serbia, No 32/2013.

${ }^{92}$ Vrhovšek, M, The Law on Confiscation of Proceeds of Crime in the Suppression of Crime - Important Link in the System of Combating Organised Crime (Zakon o oduzimanju imovine proistekle iz krivičnog dela u suzbijanju kriminala - važna karika u sistemu borbe protiv organizovanog kriminala)(Bezbednost 2010), 8-9.

${ }^{93}$ Art 33.

${ }^{94}$ See for example, Engel $v$ The Netherlands, App nos 5100/71, 5101/71, 5102/71, 5354/72, and 5370/72 (1976); and Walsh v United Kingdom, App no 33744/96 (2000).
} 
designated in the motion is not in their possession, that the lawful income is higher than that stated by the prosecutor, or that the property was acquired as inheritance, gift, etc. ${ }^{95}$

A few other provisions under this Act are worth expanding. For instance, the Act provides for financial investigations. They can be instituted when there are reasonable grounds for suspecting that the proceeds in question derived from criminal offences (Article 15), and are conducted alongside criminal investigations. ${ }^{96}$ The Act also allows temporary, as opposed to permanent, seizure of proceeds if there is a risk that subsequent seizure of the proceeds would be hindered. The safeguards here are that this is determined by an investigative judge upon the motion put forward by a public prosecutor (Article 21), and that the defendant and his/her defence lawyer will have an opportunity to challenge (Art 24).

Finally, in relation to international cooperation, the Act on Mutual Assistance in Criminal Matters ${ }^{97}$ is the main legislative framework. To begin with, this Act provides for extradition. While the general procedure is the same with other States, a few points are worth highlighting. For instance, Serbia generally does not extradite its own nationals to other States as noted earlier, with an exception of a few, such as Croatia, Montenegro, and the Former Yugoslav Republic of Macedonia with which Serbia has concluded bilateral agreements. ${ }^{98}$ This makes the principle of aut dedere aut judicare quite important in order to ensure that suspects do not evade justice, and Serbia has confirmed that it does exercise jurisdiction over its own nationals who commit organised crime abroad. ${ }^{99}$ In terms of procedural safeguards to protect the rights of suspects, the principles of double criminality, political offence exception, speciality, safeguards against trial in

\footnotetext{
95 Škulić and Ignjatović, supra n 89, 392.

${ }^{96}$ Lukić, T, Seizure of the Proceeds of Crime - Importance of Financial Investigation (Oduzimanje imovine stečene krivičnim delima - značaj finansijske istrage), Zbornik radova Pravnog fakulteta u Novom Sadu (Collection of Papers of the Law Faculty in Novi Sad 2009), 386.

${ }^{97}$ Official Gazette of the Republic of Serbia, No 20/2009 as amended.

${ }^{98}$ European Commission, Screening Report: Serbia (2014), 9-10.

${ }^{99}$ Information Submitted by States, supra n 41, 13.
} 
absentia and the death penalty, as well as some due process rights such as legal advice are recognised. ${ }^{100}$ However, the Act does not go far to include a discrimination clause reflected in Article 16 of the UNTOC. Another important point is that the Act does not currently provide for an expedite extradition procedure. The need for speedy extradition procedure for organised crime has been recognised by Serbia, and together with other States in South-East Europe, it has been considering the adoption of a Regional Convention on Arrest Warrants. ${ }^{101}$ Whether this will materialise in the future is open to question, but Serbia is an EU candidate country, and it is expected that it will implement the European Arrest Warrant when it joins in the future.

In relation to other international cooperation measures, the aforementioned Act also includes: execution of procedural activities (service of summonses and writs, hearing of the accused, examination of witnesses and experts, crime scene investigation, search of premises and persons, temporary seizure of objects); covert interception of communications and surveillance, controlled delivery; exchange of information and data; formation of joint investigative teams, and temporary surrender of a person in custody for the purpose of examination by the competent authority of the requesting state. It is therefore evident that Serbia recognises the importance of international criminal justice cooperation. In summary, the legislative frameworks on the key measures against organised crime are broadly in line with the international standards as represented by the UNTOC, and some examples of good practice are recognised.

\subsection{Critical Appraisal}

While the legislative frameworks may meet the minimum international standards, an important question to be asked is whether they are contributing to more effective action against

\footnotetext{
${ }^{100}$ Arts 7, 16 and 20.

${ }^{101}$ Regional Conference of the Ministers of Interior and Justice on Combating against Organised Crime, Corruption and Enhancing Judicial Cooperation in he SEE Region (April 2013).
} 
transnational organised crime. One important indication is the rate of prosecution and/or punishment. To begin with, it is important to recognise that Serbia has a dedicated Special Prosecutor on Organised Crime. ${ }^{102}$ The existence of such a specialised body is beneficial in order to deal with complex cases of organised crime and therefore is an example of good practice as many other States do not even have such dedicated bodies. It also sends a strong message to the general public that the Serbian government takes organised crime seriously. Nevertheless, there are a number of issues which are hampering effective law enforcement in reality. For instance, an examination of available statistical information does not point to a firm conclusion that organised crime offences are properly prosecuted and punished. In relation to human trafficking, there were 55 cases being investigated by the law enforcement authorities in 2014, compared to 33 in cases in the previous year. ${ }^{103}$ While this increase may be a positive outcome, the number of traffickers actually prosecuted and convicted has decreased between 2013 and 2014 at the same time. ${ }^{104}$ In addition, of 133 people charged by the Special Prosecutor for Organised Crime, only 60 were actually convicted in 2014. ${ }^{105}$ This can be compared with 233 conviction in 2013. ${ }^{106}$ These examples perhaps indicate that the Serbian authorities are not able to obtain high quality evidence, and the value of special investigative techniques can be called into question as a result. It has been noted in this regard that the Serbian police depends upon the security and intelligence agencies to carry out certain special investigative measures, ${ }^{107}$ suggesting that they may not have the capacity to employ them.

\footnotetext{
${ }^{102}$ Established by the Act on Organisation and Competence of State Authorities for Combating Organised Crime 2002.

${ }^{103}$ US Department of State, Trafficking in Persons Report 2015, at $<$ http://www.state.gov/j/tip/rls/tiprpt/countries/2015/243523.htm> (last accessed 10 March 2016). ${ }^{104}$ Ibid.

${ }^{105}$ Statistical Office of the Republic of Serbia, Statistical Release No.603 (Adult Perpetrators Reports, Accusations and Convictions in 2014), 31 and 53.

${ }^{106}$ Ibid, 53.

${ }^{107}$ European Commission, Serbia Progress Report 2015, 63.
} 
There are other reasons why these laws are not enforced as well as expected. For instance, corruption among the law enforcement agencies is regarded as problematic. ${ }^{108}$ The Serbia was said to have made some progress to tackle corruption, the most recent example being the adoption of the National Anti-Corruption Strategy 2013-2018. Nevertheless, corruption is an ongoing problem. One reason for this is that the police, prosecutors and judges do not have sufficient means to fight corruption. ${ }^{109}$ Other problems such as non-transparent employment procedure, poorly regulated career development, and a lack of awareness of ethical norms within the police organisation have been regarded as factors increasing the risk of corruption. ${ }^{110}$ It is important to highlight in this regard that the close to $75 \%$ of the Serbian population regard the police to be a corrupt organisation. ${ }^{111}$ In order to enhance the legitimacy of action against transnational organised crime and public confidence in law enforcement, therefore, Serbia has to do more to tackle corruption.

Another issue is obstruction of justice through witness intimidation during criminal proceedings. Their cooperation is essential in securing successful prosecution and punishment, but it has been pointed out that intimidation of witnesses, many of whom are also victims, continues, and that Serbia has not taken steps to address this. ${ }^{112}$ A lack of human, financial and other resources ${ }^{113}$ has once again been listed as one of the reasons for this. Consequently, the Law on Protection Programme for Participants in Criminal Proceedings ${ }^{114}$ is not regarded as entirely effective, and Articles 23 (obstruction of justice) and 24 (protection of witnesses) of the UNTOC are not fully implemented. Further, there is scope to consider amending Article 366 of

\footnotetext{
${ }^{108}$ Ibid, 4; and International Narcotics Control Strategy Report 2015, supra n 66.

109 Ibid, 14.

${ }^{110}$ European Union and Council of Europe, Risk Analysis of Corruption within Law Enforcement (2015), 22.

${ }^{111}$ United Nations Development Programme and the Centre for Free Election and Democracy (CeSID), Attitudes of Serbian Citizens towards Corruption (December 2013), 6.

112 Trafficking in Persons Report 2015, supra n 103.

113 European Commission, supra n 107, 16.

${ }^{114}$ Official Gazette of the Republic of Serbia, No. 85/2005.
} 
the CC which criminalises obstruction of justice. The current punishment ranges from 6 months to 5 years' imprisonment, but a question may be asked whether these serve as effective deterrence for criminals. As a way of comparison, the same offence attracts a maximum of 15 years' imprisonment in Ireland. ${ }^{115}$ Although the deterrence effect of such an increase must be carefully assessed, this can at least send a stronger message to criminals that they will face severe consequences for evading justice.

A number of issues have been identified in relation to confiscation of criminal proceeds as well. For example, it has been reported that freezing of assets at an early stage of criminal investigations rarely happens in practice, with the result that these assets disappear before the authorities are able to confiscate them. ${ }^{116}$ One reason seems to be that prosecutors often see financial investigation as part of confiscation (i.e. after one is convicted), the despite the fact that the Act allows parallel investigations alongside criminal investigations. ${ }^{117}$ The need for proper training has been recognised by the Ministry of Interior, the sentiment also felt by the European Commission and the Council of Europe. ${ }^{118}$ Such training, however, should be extended to financial and related institutions which are in a position to detect and reports suspicious activities. In this regard, a low level of reporting by these corporations has been raised as a concern. ${ }^{119}$ Another drawback is that application of the Act on Confiscation is limited in relation to money laundering, in a sense that the law enforcement authorities cannot take action unless the amount of laundered proceeds reaches at least 1.5 million Serbian dinars (approximately €12,200) in accordance with Article 231(2) of the CC.

\footnotetext{
${ }^{115}$ Section 41 of the Criminal Justice Act 1999 as amended by the Criminal Justice (Amendment) Act 2009.

${ }^{116}$ European Commission, supra n 107, 62.

${ }^{117}$ Ministry of Interior, Financial Investigation Strategy for the Period from 2015 to 2016, 8.

${ }^{118}$ Council of Europe and European Union, Criminal Asset Recovery Project in Serbia: Final Narrative Report (2013), 47.

${ }^{119}$ Committee of Experts on the Evaluation of Anti-Money Laundering Measures and Financing of Terrorism (MONEYVAL), Servia: Progress Report and Written Analysis by the Secretariat of Core Recommendations (2012), 12.
} 
Further, in relation to international law enforcement cooperation against organised crime, it is important to acknowledge from the outset that Serbia has become more proactive. In 2014, the Special Prosecutor for Organised Crime received 91 requests seeking legal assistance from States including Bosnia and Herzegovina, France, Germany, the Netherlands, Montenegro, and Slovenia. ${ }^{120}$ These requests range from delivery of writs and objects related to criminal proceedings, documents, and other evidentiary materials, to cross-border surveillance and interception of communications. ${ }^{121}$ During the same period, the Special Prosecutor submitted 42 requests for legal assistance in a variety of ways, mostly to its neighbours such as Montenegro, Bosnia and Herzegovina and Croatia. ${ }^{122}$ Aside from these examples of judicial cooperation, Serbia has been intensifying direct police-cooperation. It has, for instance, concluded a number of regional and bilateral agreements on police cooperation with a number of States, ${ }^{123}$ as well as the European agencies such as Europol. ${ }^{124}$

While these suggest that the Ministry of Interior (Central Authority for mutual legal assistance) and the courts (execution of various orders) are active in facilitating international cooperation, it has been reported that the administrative capacity of those involved needs to be strengthened, ${ }^{125}$ and there is an ongoing need for more effective training for judges. ${ }^{126}$ In relation to police cooperation, it has been reported that Serbia should make further use of mechanisms

\footnotetext{
${ }^{120}$ Ćetković, P, International Legal Assistance in Criminal Matters in the Prosecutorial Practice of the Republic of Serbia (Međunarodna pravna pomoć u krivičnim stvarima u praksi javnog tužilaštva Republike Srbije) (International Criminal Law Association 2015), 3-4.

${ }^{121}$ Ibid.

${ }^{122}$ Ibid.

${ }^{123}$ Ministry of Interior, List of International Agreements Whose Regulations Establish the Rules Relating to Exchange of Police Information and Judicial Cooperation, at $<$ http://www.seio.gov.rs/upload/documents/ekspertske\%20misije/8_list_international_agreements\%20_\%20enclosur e\%201_pdf> (last accessed 10 May 2016).

${ }^{124}$ Agreement on Operational and Strategic Cooperation between the Republic of Serbia and the European Police Office (2014).

${ }^{125}$ European Commission, supra n 98, 24.

${ }^{126}$ European Commission, supra n 107, 61.
} 
such as joint investigation teams, ${ }^{127}$ which are measures commonly utilised by the EU Member States as noted above. Further, there have been some tensions between Kosovo and Serbia in facilitating criminal justice and police cooperation. While Kosovo has concluded agreements with neighbouring States such as Albania and Montenegro, it is yet to do so with Serbia. ${ }^{128}$ This is making them and the Balkan region vulnerable to organised criminal activities as proper border control and management have yet to be implemented. ${ }^{129}$ Having said this, the problem here seems to be more political as the police forces in both Kosovo and Serbia work together directly or indirectly (through the United Nations Interim Authority in Kosovo and the EU Rule of Law Mission in Kosovo). ${ }^{130}$ In conclusion, while the legislative frameworks on organised crime, including procedural powers, exist and they more or less reflect the relevant international standards as represented by the UNTOC, their enforcement has not been as effective.

\section{Conclusion}

This article examined the implementation of international standards on action against transnational organised crime in Serbia. It is evident that Serbia is making progress steadily. The legislative frameworks on substantive offences substantive offences seem to be in line with the UNTOC. The existence of dedicated Special Prosecutor for Organised Crime is also an example of good practice. However, it was also shown that certain procedural aspects such as special investigative techniques raise human rights and other concerns. A lack of capacity and resources, which led to other serious issues such as corruption and obstruction of justice, is also an ongoing problem affecting the ability of the law enforcement authorities in tackling organised crime. A wider issue is the management of the Balkan route. The use of this route by organised

\footnotetext{
${ }^{127}$ European Commission, supra n 98, 24.

${ }^{128}$ Belgrade Centre for Security Policy, Police Cooperation between Kosovo and Serbia (2015), 4.

129 Ibid.

130 Ibid, 7.
} 
criminal groups has been known for a very long time, but the fact that drugs, arms and people continue to be trafficked through this route ${ }^{131}$ regularly clearly demonstrates that States in this region, including Serbia, have not been able to deal with the problem sufficiently. This casts further doubt on the ability and willingness of these States to promote more effective crossborder cooperation against transnational crime in the region and underscores the need for stronger external supports, particularly from European nations and institutions. Serbia’s membership to the European Union is conditional upon the successful reform of criminal law and justice system, including its capacity to tackle transnational organised crime, and a strong pressure continues to be placed upon all of those concerned to take further action.

${ }^{131}$ United Nations Office of Drugs and Crime, World Drug Report 2015, 43; and European Commission Directorate-General for Internal Policies, New Trends in the Expansion of Western Balkan Organised Crime (2012). 